\title{
Not Drowning, Trending
}

Tug Dumbly

\section{Syrian Child, Sept 2015}

The dead spokesboy remained tight-lipped

stayed on-message, under blanket

coverage on the news

Tragedy's brilliant new brand ambassador

sponsors love him-the little red shirt, little shorts and Oh, those little shoes!

Speak to his people, but don't crowd the kid he tires easily, that golden child and his picture's worth a billion views 